\title{
PERMIT REQUIREMENTS FOR DEVELOPMENT OF ENERGY AND \\ OTHER SELECTED NATURAL RESOURCES FOR THE \\ STATE OF ARKANSAS
}

\author{
PREPARED FOR \\ OZARKS REGIONAL COMMISSION \\ AND THE \\ U.S. GEOLOGICAL SURVEY \\ BY RADIAN CORPORATION
}

This technical assistance study was accomplished by professional consultants under contract with the Ozarks Regional Commission. The statements, findings, conclusions, recommendations, and other data in this report are solely those of the contractor, and do not necessarily reflect the views of the Ozarks Regional Commission or the U.S. Geological Survey.

U.S. Geological Survey Open-File Report $81-1251$ 


\title{
ACKNOWLEDGEMENTS
}

This state regulatory guide was prepared by Radian Corporation of Austin, Texas, under contract to the Ozarks Regional Commission (Contract No. 10 TA 11 28). Frank J. Iuen, 111 was the Contracting officer for the Commission. The Contracting Officer's Technical Representative was Robbi R. Dietrich. Funding for this program was provided by the U.S. Geological Survey (USGS), Resource Planning Analysis Office. Wilbert J. Ulhman was Program Director for the USGS and James Frederick was the Project Coordinator.

The Radian Program Manager was David Lewis Steed and Faith George served as Projet Director. The principal author of this guide was Anne $S$. Forrest.

The inital Liaison Officer for the State of Arkansas to the Ozarks Commission was Jule McDonald at the office of the Governor. During the project, Robert Blanz, Deputy Director of Program Operations at the Arkansas Department of Pollution Control and Ecology assumed liaison responsibilities.

Requests for information concerning this publication should be directed to the following locations:

Arkansas Department of Pollution

Ozarks Regional Commission

Control and Ecology

Post Office Box 5983

1100 North University, Suite 109

Little Rock, Arkansas 72207

Litte Rock, Arkansas 72207

or

\author{
U.S. Geological Survey \\ Environmental Affairs office \\ 760 National Center \\ Reston, Virgina 22092
}

PUBLICATION AVAILABILITY

This Arkansas Permit Guide is available as an USGS Open-File Report \#81-1251 from:

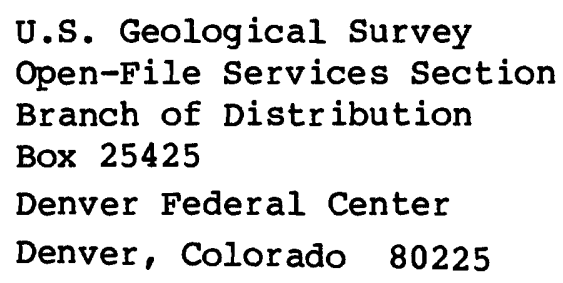


STATE PERMIT REQUIREMENTS FOR DEVELOPMENT OF ENERGY AND OTHER SELECTED NATURAL RESOURCES

STATE PERMIT GUIDES WILL BE AVAILABLE BY JANUARY 1982 FROM, USGS OPEN-FILE SERVICES SECTION, BRANCH OF DISTRIBUTION, BOX 25425, DENVER, COLORADO 80225

\begin{tabular}{|c|c|c|c|}
\hline State & Open File & State & Open File \\
\hline Alabama & $81-1248$ & Nebraska & $81-1268$ \\
\hline Alaska & $81-1249$ & New Mexico & $81-1269$ \\
\hline Arizona & $81-1250$ & New York & $81-1270$ \\
\hline Arkansas & $81-1251$ & Nevada & $81-1271$ \\
\hline California & $81-1252$ & North Carolina & $81-1272$ \\
\hline Colorado & $81-1253$ & North Dakota & $81-1273$ \\
\hline Florida & $81-1254$ & Ohio & $81-1274$ \\
\hline Georgia & $81-1255$ & Oklahoma & $81-1275$ \\
\hline Idaho & $81-1256$ & Oregon & $81-1276$ \\
\hline Illinois & $81-1257$ & Pennsylvania & $81-1277$ \\
\hline Indiana & $81-1258$ & South Carolina & $81-1278$ \\
\hline Ransas & $81-1259$ & South Dakota & $81-1279$ \\
\hline Rentucky & $81-1260$ & Tennessee & $81-1280$ \\
\hline Louisiana & $81-1261$ & Texas & $81-1281$ \\
\hline Maryland & $81-1262$ & Utah & $81-1282$ \\
\hline Michigan & $81-1263$ & Virginia & $81-1283$ \\
\hline Minnesota & $81-1264$ & Washington & $81-1284$ \\
\hline Missouri & $81-1265$ & West Virginia & $81-1285$ \\
\hline Mississippi & $81-1266$ & wisconsin & $81-1286$ \\
\hline Montana & $81-1267$ & Wyoming & $81-1287$ \\
\hline
\end{tabular}


SECTION I. INTRODUCTION

SECTION II. STATE POLICY AND PROCEDURES

Chapter 1. Pollution Control Permit Consolidation Process .............. 3

SECTION III. ENERGY EXTRACTION ........................ 5

Chapter 2. Energy Resources Exploration and Extraction .............. 5

Part A - Coal Mining Permit Process and Standards ............. 5

Part B - Permit Process and Standards for Drilling Oil, Gas, and Saltwater Injection Wells ................ 8

Part C - Permit Process and Standards for Oil, Gas, and Saltwater Injection Well Completion and the Plugging of Wells

Part D - Approval Process for the Underground Injection of Saltwater ............................. 14

Part E - Laws for the Taking of Natural Resources from State-Owned Lands

Chapter 3. Construction Materials and Metalliferous Mining ............... 19

Part A - Construction Materials and Metalliferous Mining Permit

SECTION IV. ENVIRONMENT QUALITY MANAGEMENT

Chapter 4. Air Quality Standards and Regulations $\ldots \ldots \ldots \ldots \ldots \ldots \ldots \ldots$

Part A - Plan of Implementation, Air Emissions,

Permit Process and Standards .................... 23 


\section{TABLE OF CONTENTS (Continued)}

Part B - Air Control Code Air Emission Permit Process and Standards ......................... 27

Chapter 5. Water Quality Standards and Regulations $\ldots \ldots \ldots \ldots \ldots \ldots \ldots \ldots . . \ldots \ldots$

Part A - Wastewater Permit Process and Standards ............. 37

Part B - Subdivision Sewage Disposal Permit Process and Standards $\ldots \ldots \ldots \ldots \ldots \ldots \ldots \ldots \ldots \ldots \ldots \ldots \ldots \ldots, 37$

Part C - Disposal of Oil and Gas Field Wastes Permit Process and Standards .................... 40

Chapter 6. Public Drinking Water Supply $\ldots \ldots \ldots \ldots \ldots \ldots \ldots \ldots \ldots \ldots \ldots .43$

Part A - Approval Process and Standards for Public Water Systems .............................. 43

Part B - Sewage Disposal Systems Permit Process, Standards and Subdivision Approval ................. 46

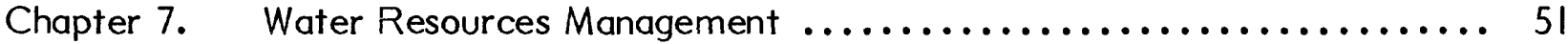

Part A - Dam Construction and Ownership Permit Process ......... 51

Part B - Arkansas Permit Process ...................... 53

Chapter 8. Non-Hazardous and Hazardous Solid Waste Management .......... 55

Part A - Solid Waste Permit Process and Standards ............. 55

Part B - Hazardous Waste Management Permit

Process Standards ........................... 58 
TABLE OF CONTENTS (Continued)

Page

Chapter 9. Noise Regulations $\ldots \ldots \ldots \ldots \ldots \ldots \ldots \ldots \ldots \ldots \ldots \ldots \ldots, 63$

SECTION V. SOCIAL AND ECOLOGICAL PRESERVATION $\ldots \ldots \ldots \ldots \ldots \ldots \ldots .65$

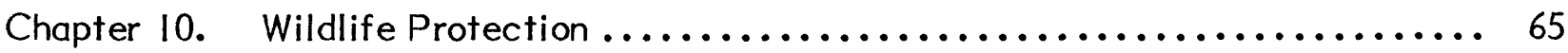

Part A - Scientific Collecting Permit Process and Standards ........ 65

Chapter 11. Archaeological and Historical Resources Protection ............. 69

Chapter 12. Wetlands Protection .............................. 71

SECTION VI. LAND USE $\ldots \ldots \ldots \ldots \ldots \ldots \ldots \ldots \ldots \ldots \ldots \ldots \ldots \ldots \ldots \ldots \ldots \ldots \ldots$

Chapter 13. Local Government Land use Enabling Laws $\ldots \ldots \ldots \ldots \ldots \ldots \ldots \ldots$

Part A - Cities ................................... 73

Part B - Counties ............................... 74

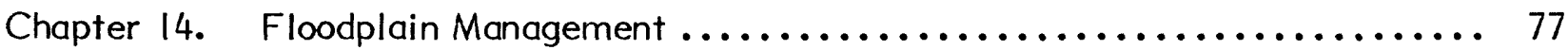

Part A - Floodplain Management Enabling Laws .............. 77

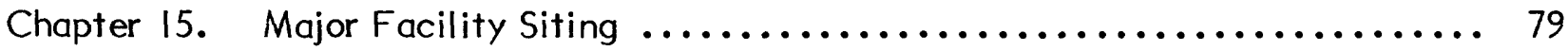

Part A - Public Utility Facility Environmental

Protection Certification Procedure .................. 79 


\section{SECTION I. INTRODUCTION}

This handbook has been compiled to assist applicants in complying with Arkansas environmental and land use regulatory programs. The handbook presents the requirements for permitting industrial projects and particularly those activities associated with energy developments. Only state programs are described, although the relationship between a state program and a parallel federal program is addressed, where appropriate. Also, only environmental protection regulatory programs are described in the handbook. Other programs, such as health and safety requirements, taxes, or zoning, which may affect a proposed activity were excluded.

The information presented is not intended to cover all aspects of the state regulatory process but is designed to provide basic procedural and information requirements and to identify programs and responsible authorities. Applicability of a program(s) to a particular activity will require confirmation by the appropriate agency(s). Also, because regulatory programs are frequently being revised, applicants should contact each agency for the latest compliance requirements.

The information presented in this handbook was obtained through review of state laws and regulations and supplemented by personal interviews with agency officials. The information is divided into the following sections:

\section{State Environmental Policy and Administrative Procedures}

\section{Resource Extraction}

Land Use Regulation

Local Regulatory Policy

Environmental Quality Management

Social/Ecological Preservation 


\section{CHAPTER I. STATE CLEARINGHOUSE AGENCY}

The Department of Pollution Control and Ecology (DPC\&E) closely resembles the concept of a state clearinghouse or one-stop permit agency. The Department has permitting jurisdiction in the areas of air quality, water quality, solid waste sanitation, environmental preservation, and mining and reclamation.

In order to increase the efficiency of permit writing and consolidate permit responsibilities, the DPC\&E has recently reorganized into two programmatic areas--program planning and program operations. As a result, the permits branch of the program operations area now has the authority for issuing all air, water, and solid waste permits. Any person who proposes to site a facility which has the potential to pollute must complete a single application form for these permits.

Two completed copies of the "Pollution Control Permit Application" must be submitted for each type of waste generated (air, water, solid waste). The application form specifically requires the following information: the name, address, and phone number of the applicant, the facility, contact persons, and the engineering consulting firm; the location of the facility; the permit classification (new or existing facility, change in location, change in ownership); a description of the business; type of discharge (air, water and/or solid waste); estimated cost of control equipment; proposed construction commencement and completion dates; and appropriate signatures. Several enclosures are required with the application. These include an area map; a plot plan; a process flow diagram; a description of the process; materials balance information; effluent and emission data; a description of the sampling program; and construction plans, specifications, and design calculations.

Additional information may be required for large sources of air emissions, wastewaters, or solid wastes. This will be determined by the Department after receipt 
of the application and the applicant will be notified. Applicants for solid waste permits must also complete a preapplication form.

While the application form is the same for the air, water, and solid waste permits, this guidebook discusses each permit process and applicable standards separately under the appropriate section. Thus, air permits are discussed in Chapter 4, Parts $A$ and $B$, water permits in Chapter 5, Parts $A, B$, and $C$ and solid waste in Chapter 8, Part A.

The applicable agency contact information for the air, water, and solid waste permits is the following:

\author{
Permits Branch \\ Department of Pollution Control and Ecology \\ 8001 National Drive \\ Little Rock, Arkansas 72219 \\ (50I) $371-1135$
}


SECTION III. ENERGY EXTRACTION

\section{CHAPTER 2. ENERGY RESOURCES EXPLORATION AND EXTRACTION}

A number of regulations govern energy resource extraction in Arkansas. The Arkansas Surface Coal Mining and Reclamation Act of 1979 regulates coal mining. To administer the Act, the Department of Pollution Control and Ecology has adopted the Surface Mining Enforcement and Reclamation Regulations. Oil and gas exploration is regulated by the Oil and Gas Commission. Act 105 of 1939, as amended, authorizes the Commission to regulate the drilling and plugging of oil and gas wells. Also under the authority of this Act, the Commission regulates the underground injection of saltwater. Finally, Act 524 of 1975 regulates the taking of certain natural resources from state lands. This Act is administered by the Department of Commerce.

Part $A$ of this Chapter discusses the permit process and standards which govern coal mining and reclamation. The permit process and standards regulating the drilling of oil and gas wells are covered in Part B, and Part C describes the permit process and standards which govern the plugging of wells. Part $D$ describes the approval process and the standards of the Oil Gas Commission concerning the underground injection of saltwater. Finally, the Department of Commerce's state land leasing laws are found in Part $E$.

PART A. Coal Mining Permit Process and Standards

1. Authorizing Statute

Arkansas Surface Coal Mining and Reclamation Act of 1979

(Arkansas Statutes Annotated, Sections 52-934, et seq.)

2. Title of Regulations

Surface Mining Enforcement and Reclamation Regulations. 
3. Summary of Permit Process

a. Applicability

The mining or reclaiming of any surface or underground coal mine is subject to the regulations.

b. General Requirements

A permit is required for the mining of coal.

c. Submittal Requirements

A completed application identifying and describing the location of the site, with a mining and reclamation plan demonstrating compliance with performance standards must be submitted. General information describing environmental resources in the area must also be submitted. Before the permit can be issued, a bond sufficient to cover the cost of reclamation must be posted with the DPC\&E. Phased bonding is allowed.

d. Public Hearing

A public hearing may be held on request.

e. Time Requirements

An application must be filed at least 90 days prior to commencement of operations.

f. Fees

A $\$ 500.00$ permit review fee must be submitted with the application. 


\section{g. Appeals Process}

The permit applicant may appeal a permit denial to the Commission of Pollution Control and Ecology. The Commission meets regularly on the fourth Friday of odd months (January, March, etc.) and at special meetings as required.

4. General Standards

a. Applicability

The mining and reclamation of any surface underground coal mine is subject to the regulations.

b. General Requirements

Performance standards for the operation and reclamation of mines have been adopted. Such standards have been developed in the following major areas: casing and sealing of openings, topsoil removal and replacement, hydrologic balance, use of explosives, waste disposal, coal processing waste banks, backfilling and grading, revegetation, subsidence control and roads. Coal exploration operations are also subject to standards. A notice of intent to explore must be filed with the Department. If more than 250 tons of coal are removed from the area during exploration, the operator must obtain written approval of the Department.

\section{c. Submittal Requirements}

The Director of DPC\&E may require the operator to monitor activities and report them to the Department. 


\section{d. Time Requirements}

Mining operations must begin within three years after the permit is issued.

5. Administering Agency

Surface Mining and Reclamation Division

Department of Pollution Control and Ecology

8001 National Drive

Little Rock, Arkansas 72219

(501) $371-1135$

6. Relation to Other State and Federal Programs

The DPC\&E may notify other state agencies, such as the Soil and Water Commission, Forestry Commission, Arkansas Archaeology Survey and the Arkansas Department of Natural and Cultural Heritage of the application for a surface mining permit and request review. A permit may not be approved unless applicant demonstrates that the proposed action will not adversely affect an existing or eligible National Register historic site property. This finding must be stated in writing.

The Arkansas Surface Mining Act is an approved state program pursuant to the federal Surface Mining Control and Reclamation Act (SMCRA).

PART B. Permit Process and Standards for Drilling Oil, Gas and Saltwater Injection Wells

1. Authorizing Statute

Act 105 of 1939, as amended (Arkansas Statutes Annotated, Sections 53- 101 et seq.) 
2. Title of Regulations

General Rules and Regulations, Order No 2-39.

3. Summary of Permit Process

a. Applicability

The drilling of new wells is subject to the regulations, unless specifically exempted.

b. General Requirements

A permit is required for the drilling of oil, gas, brine, or saltwater injection wells.

c. Submittal Requirements

A completed application including a characterization of the well, the location of the well, and the intended drilling date must be submitted. If the applicant intends to dispose of saltwater in a well, approval from the Commission as described in Part C must be obtained in addition to the drilling permit.

d. Public Hearings

No public hearing is required.

e. Time Requirements

The drilling of the well must occur within three months of the application date or the permit becomes void. 


\section{f. Fees}

A fee of $\$ 150.00$ is required.

\section{g. Appeals Process}

Upon the denial of a permit, an applicant may request a public hearing. In the public hearing, the applicant may request an exemption from the regulations.

\section{General Standards}

\section{a. Applicability}

The construction and operation of all oil, gas, brine, or saltwater injection wells are subject to the regulations.

b. General Standards and Requirements

Standards for the construction, operation, and maintenance of a well have been developed. For example, casing requirements have been set for each type of well. Wells in proven fields are governed by special rules for the field or area. The use of certain types of equipment in a producing well is also prohibited.

\section{c. Submittal Requirements}

During the drilling or recompletion of each well, adequate records of the well being drilled must be maintained. "Well Status Reports and Gas/Oil Ratio" records must be submitted to the Commission monthly. 
5. Administering Agency

Oil and Gas Commission

314 East Oak Street

El Dorado, Arkansas 71730

(50I) $862-4965$

6. Relation to Other State and Federal Programs

See Part D-6 of this Chapter.

PART C. Permit Process and Standards for Oil, Gas, and Saltwater Injection Well Completion and the Plugging of Wells

1. Authorizing Statute

Act 105 of 1939, as amended (Arkansas Statutes Annotated, Sections 53- 101 et seq.)

2. Title of Regulations

General Rules and Regulations, Order No. 2-39.

3. Summary of Permit Process

a. Applicability

The completion and plugging of any well is subject to the regulations.

b. General Requirements

A permit is required for the plugging of any oil, gas, brine, or saltwater injection well. 


\section{c. Submittal Requirements}

A completed application including a description and characterization of the well and a description of its location and depth must be submitted before plugging may be performed.

d. Public Hearing

No public hearing is required.

e. Time Requirements

According to the regulations, the Commission must be notified at least three days before plugging is to occur. This time requirement may be waived by the Commission.

\section{f. Fees}

No fees are required.

g. Appeals Process

No appeals process is specified in the regulations.

4. General Standards

a. Applicability

The completion and plugging of any well must be performed in compliance with standards.

b. General Standards and Requirements

Plugging procedures have been developed. The Commission must physically oversee plugging operations. All holes must be 
properly cased or abandoned in accordance to methods described in Rule B-8 of the Regulations.

\section{c. Submittal Requirements}

Upon completion or recompletion of a well, the operator shall file the following, if applicable: a complete "Well Completion Report," any electric logging or surveying of the well base, a certification of compliance and "Authorization to Transport," "Application to Abandon," and/or a "Report of Abandonment." After a well has been plugged, an affidavit documenting plugging method must be filed with the Commission.

\section{d. Time Requirements}

The appropriate reports listed above should be filed within five days of the completion of a well. The "Affidavit of Method of Plugging" must be filed with the Commission within five days of plugging.

5. Administering Agency Contact Information

Oil and Gas Commission

314 East Oak Street

El Dorado, Arkansas 71730

(501) 862-4965

6. Relation to Other State and Federal Programs

None specified. 
PART D. Approval Process for the Underground Injection of Saltwater

1. Authorizing Statute

Act 105 of 1939, as amended (Arkansas Statutes Annotated, Sections 53-101 et seq.)

2. Title of Regulations

General Rules and Regulations, Order No. 2-39.

3. Summary of Process

a. Applicability

The underground disposal of saltwater or other water containing minerals is subject to the regulations.

b. General Requirements

The approval of the Commission is required before saltwater may be disposed in any well. Trial tests may be allowed by the Commission.

c. Submittal Requirements

A completed application including a characterization of the depth of the well, a map of the area surrounding the well, information on the location of source(s) of the water to be disposed, and an estimate of the volume of water to be injected must be submitted. If the applicant proposes to drill the well in which saltwater will be injected, an appliation to drill must also accompany the injection approval request. 
d. Public Hearing

No public hearing is required. However, all well operators within a specified radius of a well must be notified of the proposed action.

e. Time Requirements

Operators that are notified of the application may file objections within ten days of notification.

f. Fees

No fees are specified in the regulations.

g. Appeals Process

If the Commission denies the application, the applicant may request a public hearing. In the public hearing, the applicant may request an exemption from the regulations.

4. General Standards

a. Applicability

The underground injection of saltwater or other water containing minerals must occur in compliance with the regulations.

b. General Requirements

Requirements as to where liquids can be disposed of have been developed. Disposal wells shall be cased and the casing cemented in such a manner that damage will not be caused to oil, gas, and fresh water resources. The applicant must notify the Commission of commencement of disposal activities. 


\section{c. Submittal Requirements}

Adequate records of the amount of water disposed of in the well shall be kept and furnished to the Commission monthly in the "Sal twater Disposal Report."

\section{d. Time Requirements}

Within ten days after discontinuance of disposal operations, the well operator must notify the Commission of the date and reasons for discontinuance. Before any disposal well is abandoned, notice must be served on the Commission and procedures described under Part $C$ shall be undertaken.

5. Administering Agency

Oil and Gas Commission

314 East Oak Street

EI Dorado, Arkansas 71730

(501) 862-4965

6. Relation to Other State and Federal Programs

The Oil and Gas Commission regulates the below ground disposal of saltwater and other oil and gas field wastes. The DPC\&E regulates above ground disposal of such wastes. The Commission and the Department issue separate regulations. The Department's regulations are discussed in Section IV, Chapter 5, Part C.

PART E. Laws for the Taking of Natural Resources From State-Owned Lands

1. Authorizing Statute

Act 524 of 1975, as amended by Act 684 of 1981 (Arkansas Statutes Annotated, Sections 10-1014, et seq.) 
2. Title of Regulations

Rules and Regulations Pertaining to the Granting of Leases and Permits for the Taking of Sand and Gravel, Minerals, and Timber from State-Owned Lands.

Regulations for Act 684 have not yet been promulgated.

3. Summary of Procedures

a. Applicability

The taking of sand and gravel, oil, natural gas, casinghead gas, coal, minerals, or the severance of timber from state-owned lands is subject to the regulations.

b. General Requirements

A lease or permit is required from the Department of Commerce to take sand and gravel, oil, natural gas, casinghead gas, coal, minerals, or the severance of timber from state-owned lands.

c. Submittal Requirements

Submittal requirements differ by resources. Generally applicant must submit approved form containing a legal description of property and type of resources to be taken. The offering of bonuses or earnest money may also be required.

d. Public Hearing

No public hearing is required. However, a legal notice is published seeking competitive bids. 
e. Time Requirements

Time requirements for responding to bids are prescribed in the regulations. The time period allowed for submitting bids must be a minimum of twenty days.

\section{f. Fees}

A $\$ \mid 25.00$ fee is charged to cover advertising and administrative costs.

\section{g. Appeals Process}

No appeals process is specified in the regulations.

4. Administering Agency

Department of Commerce

6th Floor, I Capital Mall

Little Rock, Arkansas 72201

(501) $371-2231$

5. Relation to Other State and Federal Programs

The Department of Commerce must notify the Game and Fish Commission, Department of Parks and Tourism, Department of Pollution Control and Ecology, Oil and Gas Commission, Geological Survey, Forestry Commission, Soil and Water Conservation Commission, and all other agencies that have an interest in the proposed action. These agencies are to investigate the proposed action and report findings and make recommendations to the Department of Commerce (DOC). The Director of DOC may deny or grant a permit or lease subject to such conditions or requirements as he deems appropriate to protect the interests of the state. 
The Open Cut Land Reclamation Act of 1977 regulates the mining of construction materials and metals. The Act is administered by the Department of Pollution Control and Ecology which has developed departmental guidelines entitled "Implementation of the Open Cut Mining Law for Administrative Purposes" to implement the Act. Part A of this Chapter describes the permit process and standards required by the guidelines.

PART A. Construction Materials and Metalliferous Mining Permit

I. Authorizing Statute

Open Cut Land Reclamation Act (Arkansas Statutes Annotated, Sections 52-901, et seq.)

2. Title of Regulations

Department Guidelines.

Implementation of the Open Cut Mining Law for Administrative Purposes.

3. Summary of Permit Process

a. Applicability

The mining of sand, gravel, kaolin, bauxite, and barite is subject to the regulations. The non-commercial removal of sand, gravel, stone, shale or soil from lands by the owner of the lands is exempted as are dredge operations and quarries. Activities during the construction of streets or highways are also specifically exempted. 
b. General Requirements

A permit is required for all new open cut non-coal mines. An operator is deemed to be engaging in open cut mining when he removes any amount of overburden in preparation for mining.

c. Submittal Requirements

A completed application containing a description and location of the mine, and a mining and reclamation plan must be submitted. $A$ bond to cover reclamation costs must also be submitted upon approval of application.

d. Public Hearing

No public hearing is required.

e. Time Requirements

The Commission must issue appropriate permit or disapprove application within 30 days after a completed application with bond has been filed.

\section{f. Fees}

Fees are based on number of acres mined:

Up to 2 acres - $\$ 25.00$

2 to 10 acres - $\$ 200.00$

10 to 50 acres - $\$ 510.00$

Each 50 acres

above original

50 acres - $\quad \$ 500.00$ 
g. Appeals Process

An appeal may be requested from the Commission of Pollution Control and Ecology within 30 days of the permit decision. The Commission meets once every two months.

4. General Standards

a. Applicability

Mining of sand, gravel, kaolin, bauxite and barite mines is subject to the regulations.

b. General Requirements and Standards

Standards have been set as to how land may be developed, reclaimed and maintained. For instance, the regulations state that all ridges or peaks of land affected by mining shall be graded to rolling or terraced topography with adequate drainage.

c. Submittal Requirements

The operator must submit a map and description of land affected by open cut mining during the permit term and the extent of completed reclamation. The report shall be submitted annually on the first day of June.

d. Time Requirements

No time requirements are specified in the regulations. 
5. Administering Agency

Surface Mining and Reclamation Division

Department of Pollution Control and Ecology

8001 National Drive

Little Rock, Arkansas 72219

(501) $371-1135$

6. Relation to Other Federal and State Programs

None specified. 
In 1965, the Arkansas Legislature amended Act 472 of 1949 to give the Department of Pollution Control and Ecology responsibility for air pollution control. To implement the Act, entitled the Arkansas Water and Air Pollution Control Act, the Department has adopted two sets of regulations: Regulations of the Arkansas Plan of Implementation for Air Pollution Control (The State Implementation Plan or SIP) and the Arkansas Air Pollution Control Code. The SIP is supplemented by Regulations for the Control of Volatile Organic Compounds which apply only to sources in Pulaski County. The permit process and standards for the Plan of Implementation are discussed in Part A.

The Arkansas Air Pollution Control Code regulates all sources not included in the Plan of Implementation regulations, unless these sources are specifically exempted. The permit process and standards for the Air Control Code are discussed in Part B.

PART A. Plan of Implementation, Air Emissions Permit Process, and Standards

I. Authorizing Statute

Arkansas Water and Pollution Control Act (Arkansas Statutes Annotated, Sections 82-1901, et seq.)

2. Title of Regulations

Regulations of the Arkansas Plan of Implementation for Air Pollution Control

and

Regulations for the Control of Volatile Organic Compounds. 


\section{Summary of Permit Process}

a. Applicability

The construction of new equipment or the modification or relocation of existing equipment which has the potential to emit more than 100 tons of a criteria pollutant annually is subject to the regulations. "Equipment" is defined as any device capable of causing the emission of an air contaminant into the open air and any stack serving that equipment.

Also, Pulaski County is a non-attainment area for ozone and therefore subject to special hydrocarbon or VOC control. Any equipment emitting volatile organic compounds that is constructed or modified in Pulaski County is also subject to the regulations.

Criteria pollutants are those for which a National Ambient Air Quality Standard (NAAQS) has been established by the federal Environmental Protection Agency. Criteria pollutants include particulate matter, sulfur dioxide, nitrogen dioxide, ozone, carbon monoxide, lead, and non-methane hydrocarbons.

\section{b. General Requirements}

A permit is required for any new equipment or modification of existing equipment emitting air contaminants as characterized above. New sources in Pulaski County must obtain emissions offsets for VOC before a permit may be issued.

\section{c. Submittal Requirements}

Applicant must submit a completed application showing that equipment will be installed or modified to operate without exceeding the allowable emissions rate as stated in the 
standards. Specific submittal requirements of the application are stated in Chapter 1--Pollution Control Permit Consolidation Process. The Director of DPC\&E may require submittal of additional information. Application for incinerators must follow the same submittal requirements; however, such facilities receive a different permit.

\section{d. Public Hearing}

A public hearing may be held on request. The public is allowed the opportunity to comment on a proposed action.

e. Time Requirements

The DPC\&E is required to notify the applicant of its approval or disapproval of the permit application within 90 days after submittal, unless the public comment period is extended.

The Director may cancel a permit if the installation or alteration is not begun within 18 months from the date of the permit or if work is suspended for 18 months or more.

\section{f. $\quad$ Fees}

No fees are required.

\section{g. Appeals Process}

Upon the denial of a permit, the applicant may request a hearing before the Commission on Pollution Control and Ecology. The Commission meets regularly on the fourth Friday of all odd months and at special meetings as required. 
4. General Standards

a. Applicability

Standards are applicable to new construction or modifications with potential to emit more than 100 tons of a criteria pollutant. (See discussion in this Part, Section 3.a above.)

b. General Requirements

Allowable emission rates have been established for two air pollutants--particulates and volatile organic compounds. No person shall cause or permit the construction or modification of equipment which would cause or exceed the allowable emissions rates.

c. Submittal Requirements

The Director of DPC\&E may require any person owning or operating equipment to conduct sampling of emissions and submit sampling reports to the Department.

d. Time Requirements

Copies of all data, computations, and results obtained under the Plan of Implementation Regulations shall be retained by the owner for at least five years. 
5. Administering Agency

Permits:

Permits Branch

Department of Pollution Control and Ecology

8001 National Drive

Little Rock, Arkansas 72209

(50I) $371-1135$

Standards:

Air Division

Department of Pollution Control and Ecology

8001 National Drive

Little Rock, Arkansas 72219

(50I) 37I- I 70I

6. Relation to Other State and Federal Programs

The Plan of Implementation was developed pursuant to the federal Clean Air Act. No state regulations regulate the emission of other criteria pollutants. Federal requirements apply where there are no state regulations.

PART B. Air Control Code Air Emission Permit Process And Standards

1. Authorizing Statute

Arkansas Water and Air Pollution Control Act (Arkansas Statutes Annotated, Sections 82-1901, et seq.)

2. Title of Regulations

Arkansas Air Pollution Control Code, as amended. 


\section{Summary of Permit Process}

a. Applicability

The installation, alteration or replacement of any equipment or control apparatus that is not specifically exempted in Section 3(d) of the Code is subject to the regulations. Exempted equipment includes air contaminant detectors or recorders; cooling and ventilation equipment; cleaning, washing and drying equipment; furnaces, ovens, heaters; testing and inspection equipment; and some types of miscellaneous equipment. The Air Pollution Control Code applies to equipment or control devices (unless exempted) that are not subject to Plan of Implementation regulations.

\section{b. General Requirements}

A permit is required for any equipment or control device characterized above.

\section{c. Submittal Requirements}

Specific submittal requirements of the application are stated in Chapter 1--Pollution Control Permit Consolidation Process. The applicant must submit a completed application containing a description of the stack emission sampling program proposed by the applicant. The Director of DPC\&E may waive or modify these requirements. Applications for incinerators must follow the same submittal requirement; however, such facilities receive a different permit.

\section{d. Public Hearing}

A public hearing may be held on request. 
e. Time Requirements

DPC\&E is required to notify the applicant of its approval or disapproval of the permit application within 90 days after receipt of all necessary information.

Construction, installation, or modification of permitted equipment must begin within one year from the date of a permit.

\section{f. Fees}

No fees are required.

\section{g. Appeals Process}

Upon the denial of a permit, the applicant may request a hearing before the Commission on Pollution Control and Ecology. The Commission meets regularly on the fourth Friday of all odd months and holds special meetings as required.

4. General Standards

a. Applicability

The installation, alteration or replacement of any equipment or control apparatus that is not specifically exempted in Section 3(d) of the Code is subject to the regulations. Exempted equipment includes air contaminant detector or recorders; cooling and ventilation equipment; cleaning, washing and drying equipment; furnaces, ovens, heaters, testing and inspection equipment; and some types of miscellaneous equipment. The Air Pollution Control Code applies to equipment or control devices (unless exempted) that are not subject to Plan of Implementation regulations. 
b. General Requirements

Allowable emissions rates have been established for two air pollutants--particulates and sulfur dioxide. Additional caseby-case restrictions may be required by permit conditions.

c. Submittal Requirements

The Director of DPC\&E may require any person owning or operating equipment to conduct sampling of emissions and submit them to the Department.

\section{d. Time Requirements}

No time requirements are specified in the regulations.

5. Administering Agency

Permits:

Permits Branch

Department of Pollution Control and Ecology

8001 National Drive

Little Rock, Arkansas 72209

(501) $371-1135$

Standards:

Air Division

Department of Pollution Control and Ecology

8001 National Drive

Little Rock, Arkansas 72219

(501) $371-1701$ 
6. Relation to Other State and Federal Programs

The Air Control Code regulates all air emissions sources which are not regulated by the Plan of Implementation regulations.

No state regulations regulate the emission of other criteria pollutants. Federal requirements apply where there are no state regulations. 
The Arkansas Water and Air Pollution Control Act was enacted in response to the requirements imposed by the Federal Water Pollution Control Act of 1972 and amendments. Part 1 of the Arkansas Pollution Control Act applies to water pollution control. To protect water quality under this Act, the Department of Pollution Control and Ecology (DPC\&E) has adopted controls in the form of wastewater permits and water quality standards. These controls are described in Part A. The Department also controls water quality through subdivision wastewater management permits and standards. These controls are discussed in Part B. Finally, the Department's water quality related permits and standards for the disposal of wastes from oil and gas fields are described in Part $C$.

PART A. Wastewater Permit Process and Standards

1. Authorizing Statute

Arkansas Water and Air Pollution Control Act (Arkansas Statutes Annotated, Sections 82-1901, et seq.)

2. Title of Regulations

The permit process has been developed by the DPC\&E in compliance with the Department's Regulations 1-4 and applicable guidelines.

3. Summary of Permit Process

a. Applicability

The following actions are subject to the regulations: construction or modification of a facility with wastewater discharge (includes wastewater treatment facilities); or an increase in the volume or strength of sewage or a change in the characteristics of the wastewater from a facility. 
b. General Requirements

A permit is required for each facility that has the potential for discharging wastewater.

c. Submittal Requirements

Specific requirements are specified in Chapter I-Pollution Control Permit Application.

d. Public Hearing

The Director of DPC\&E may hold a hearing at his discretion if he determines that permitting the proposed action represents a significant public issue.

e. Time Requirements

The time required for permit processing will vary with the size and types of treatment facilities involved. However, a minimum of 90 days should be allowed for processing.

f. Fees

No fees are required.

g. Appeals Process

Within 30 days of a permit denial, the applicant may request a hearing before the Commission of Pollution Control and Ecology. The Commission meets regularly on the fourth Friday of all odd months and holds special meetings as required. 
4. General Standards

a. Applicability

All sources discharging into certain waters of the state are subject to the quality standards and effluent limitations specified in the wastewater permit.

b. General Standards

Qualitative in-stream standards have been adopted based on three classes of water use and fishery types. Standards are designed to protect water quality throughout the state and are not linked to specific sources of discharge.

c. Submittal Requirements

No submittal requirements are specified in the regulations.

d. Time Requirements

No time requirements are specified in the regulations.

5. Administering Agency

Permits:

Permits Branch

Department of Pollution Control and Ecology

800I National Drive

Little Rock, Arkansas 72209

(501) $371-1135$ 


\section{Standards:}

Water Division

Department of Pollution Control and Ecology

8001 National Drive

Little Rock, Arkansas 72219

(501) $371-1701$

6. Relationship to Other State and Federal Programs

Permits issued under the state program are coordinated with the federal National Pollutant Discharge Elimination System (NPDES) program where applicable. All wastewater discharges require a federal NPDES permit in addition to the state permit from the Department.

Any wastewater treatment facility treating domestic sewage must also be approved by the Department of Health.

All wastewater treatment plant operators must be licensed under the provisions of Act 211 of 1971. The Rules and Regulations Governing the Certification of Wastewater Utilities Personnel require that all applicants for an operator's license pass the examination given by the DPC\&E. Applicants must file an application with DPC\&E.

Any facility disposing of wastewater by underground injection must also receive approval from the Oil and Gas Commission. These regulations are described in Section III, Chapter 2, Part D.

All mining operations require a permit from the Surface Mining and Reclamation Division of the Department. The mining permit is discussed in Section III, Chapter 2, Part A. 
PART B. Subdivision Sewage Disposal Permit Process and Standards

1. Authorizing Statute

Arkansas Water and Air Pollution Control Act (Arkansas Statutes Annotated, Sections 82-1901, et seq.)

2. Title of Regulations

Regulation to Require a Disposal Permit for Real Estate Subdivisions in Proximity to Lakes and Streams.

Regulation No. 4.

3. Summary of Permit Process

a. Applicability

The subdividing of land located within 2,640 feet of a lake or stream is subject of the regulations. Affected streams are listed in "Schedule $A$ " of the regulations.

b. General Requirements

A permit is required for each disposal system on land that is subdivided for residential, industrial or commercial lots within 2,640 feet of a lake or stream.

c. Submittal Requirements

Detailed plans and specifications of type of wastewater collection system to be used and an overall management plan providing for the phasing in of the wastewater treatment system must be filed. 
d. Public Hearing

No public hearing is required.

e. Time Requirements

No time requirements are specified in the regulations.

f. Fees

No fees are required.

g. Appeals Process

No appeals process is specified in the regulations.

4. General Standards

a. Applicability

All subdivisions with 2,640 feet of a lake or stream are subject to the regulation.

b. General Standards and Requirements

Wastewater from subdivisions located in proximity to lakes and streams must be treated using Best Management Practices.

c. Submittal Requirements

The regulations do not require that any information be submitted. 
d. Time Requirements

No time requirements are specified in the regulations.

5. Administering Agency

Permits:

Permit Branch

Department of Pollution Control and Ecology

8001 National Drive

Little Rock, Arkansas 72219

(501) $371-1135$

Standards:

Water Division

Department of Pollution Control and Ecology

8001 National Drive

Little Rock, Arkansas 72219

(501) $371-1701$

6. Relation to Other State and Federal Programs

The Department of Health must review any management plan submitted to DPC\&E before a permit may be issued. The Department's approval process is described in Section IV, Chapter 6, Part B.

A federal National Pollutant Discharge Elimination System (NPDES) may also be required if the development plan contains a point source discharge into a water body. 
PART C. Disposal of Oil and Gas Field Wastes Permit Process Standards

1. Authorizing Statute

Arkansas Water and Air Pollution Control Act (Arkansas Statutes Annotated, 82-1901, et seq.)

2. Title of Regulation

Regulation for the Prevention of Pollution by Salt Water and Other Oil Field Wastes Produced by Wells in New Fields or Pools. Regulation No. 1 .

3. Summary of Permit Process

a. Applicability

The construction or operation of a disposal system for wells emitting wastes is subject to the regulations.

b. General Requirements

All oil and gas wells in a new field or pool must be permitted.

c. Submittal Requirements

Plans and specifications for a disposal system adequate to prevent discharge into the waters of the state must be submitted within 30 days of initial waste production.

d. Public Hearing

No public hearing is required. 
e. Time Requirements

Application for a permit must be made within 30 days after well has produced any such wastes.

f. Fees

No fees are required.

g. Appeals Process

Within 30 days of the denial of a permit, the applicant may appeal to the Director of DPC\&E.

4. General Standards

a. Applicability

All oil and gas wells are subject to the regulations.

b. General Requirements

The discharge of oil or saltwater to the open ground or into water of the state is prohibited.

c. Submittal Requirements

Increases in the volume of salt water or other wastes produced by a permitted well must be reported to the Commission.

d. Time Requirements

No time requirements are specified in the regulations. 
5. Administering Agency

Department of Pollution Control and Ecology

P.O. Box 851

El Dorado, Arkansas 71730

(501) 862-5941

6. Relation to Other Federal and State Programs

Both the Department of Pollution Control and Ecology (DPC\&E) and the $\mathrm{Oil}$ and Gas Commission (OGC) have authority to regulate underground injection. Permitting authority is shared by the Department and the Commission. Generally, the DPC\&E regulates the above ground discharge of saltwater and other oil and gas field wastes. The Oil and Gas Commission regulates the below ground disposal of such wastes. The Department and the Commission issue separate permits and regulations. The Commission's regulations are discussed in Section III, Chapter 2, Parts C and D.

Act 523 of 1981 authorizes DPC\&E and/or OGC either singularly or jointly to acquire primary enforcement responsibility for the control of underground injection under the applicable provisions of the federal Safe Drinking Water Act. No state program had been developed as of April, 1981. 
Under Act 96 of 1913, as amended, and the Sewage Disposal System Act, respectively, the Department of Health has responsibility for approving the construction and operation of public water systems and for approving the construction and operation of all sewage disposal systems in the state. Part A of this section describes the Department of Health's approval process and standards for public water systems. Part B discusses the permit process and standards and subdivision approval process of the Department relating to sewage disposal systems.

PART A. Approval Process and Standards for Public Water Systems

1. Authorizing Statute

Act 96 of 1913, as amended (Arkansas Statutes Annotated, Sections $82-110$ et seq.)

2. Title of Regulations

Rules and Regulations Pertaining to Public Water Systems.

3. Summary of Review Process

a. Applicability

All public water systems that have at least 15 service connections or those that regularly serve an average of at least 25 individuals daily at least 60 days out of the year are subject to the regulations. 


\section{b. General Requirements}

The Department of Health must approve all plans and specifications for public water systems before a contract may be entered into or construction may begin.

c. Submittal Requirements

A preliminary report containing data and information sufficient for the "complete understanding of the proposed work" must first be submitted. Complete plans and specifications fully describing the work must then be reviewed and approved by the Department.

d. Public Hearing

A public hearing is not required.

e. Time Requirements

No time requirements are specified in the regulations.

f. Fees

A review fee of one half of one percent of the estimated cost of the system must be submitted with the final report. The maximum fee charged is $\$ 250.00$. No fee is required when the estimated cost of a system is less than $\$ 2,500.00$.

g. Appeal Process

Any aggrieved person may request a hearing before the Board of Health. 
4. General Standards

a. Applicability

All public water systems that have at least 15 service connections or those that regularly serve an average of at least 25 individuals daily at least 60 days out of the year are subject to the regulations.

b. General Requirements

System design and performance standards have been prescribed for water treatment plants, potable water storage tanks, pump stations and distribution systems. Standards have also been set for the protection of ground and surface water quality.

c. Submittal Requirements

No submittal requirements are specified in the regulations.

d. Time Requirements

No time requirements are specified in the regulations.

5. Administering Agency

Department of Health

Division of Engineering

4815 West Markham

Little Rock, Arkansas 72201

(501) $661-2623$ 
6. Relation to Other State and Federal Programs

Every owner of a water supply system must operate the system so as to meet the standards set forth in the National Primary Drinking Water Regulation of the federal Safe Drinking Water Act.

All operators of public water systems shall be licensed and certified under the provisions of Arkansas Act 333 of 1957. The Rules and Regulations Pertaining to Water Supply Operator Licensing require that all applicants for an operator's license pass an examination given by the Department of Health. Operators are defined as managers, assistant managers, superintendents, assistant superintendents, construction foremen, treatment plant personnel and persons responsible for the operation and maintenance of wells, reservoirs, and pumping facilities.

PART B. Sewage Disposal Systems Permit Process, Standards And Subdivision Approval

1. Authorizing Statute

Arkansas Sewage Disposal Systems Act (Arkansas Statutes Annotated, Sections 19-5401 et seq.)

2. Title of Regulations

Rules and Regulations Pertaining to Sewage Disposal Systems and Installers Section 7--Permits and Inspections

3. Summary of Permit Process

a. Applicability

The construction, alteration, or repair of any individual sewage disposal system is subject to the regulations. 
b. General Requirements

A Permit for Construction is required prior to the construction of any system. During the construction of the system, an inspection will be conducted by a Health Department representative. The construction permit holder must notify the Health Department when the inspection should be made. If the construction is satisfactory, a Permit for Operation is issued.

c. Submittal Requirements

An "Application for Individual Sewage Disposal Permit" must be submitted to the County Sanitarian before construction can take place. A completed application including a drawing of the site showing the building location, the location of percolation tests, the septic tank and absorption field layout, the location of wells and other pertinent information must be submitted.

d. Public Hearing

A public hearing is not required.

e. Time Requirements

No time requirements are specified in the regulations.

f. Fees

A $\$ 5.00$ review fee is charged.

g. Appeals Process

Any aggrieved person may request a hearing before the Board of Health. 
4. General Standards for Sewage Disposal Systems

a. Applicability

All sewage disposal systems must be in conformance with the regulations.

b. General Requirements

Standards for the design, construction, and operation of sewage disposal systems have been developed. For example, minimum lot sizes are specified when a septic tank absorption field system is proposed.

c. Submittal Requirements

No submittal requirements are specified in the regulations.

d. Time Requirements

No time requirements are specified in the regulations.

5. Summary of Approval Process for Subdivision Sewage Disposal Systems

a. Applicability

All subdivision plans using individual sewage disposal systems for sewage treatment must be submitted for review.

b. General Standards and Requirements

Suitability requirements have been established for sewage disposal systems in subdivisions. 
c. Submittal Requirements

Subdivision plans and specifications must be submitted. Data on percolation tests and soil determinations, their locations, the details of the septic tank, the distribution box, the leaching field, the sand filter or other sewage treatment facilities as well as information on the volume of the sewage flow must also be included.

d. Time Requirements

The approval of the Department of Health is required before construction may be started or before a contract to construct may be entered into.

6. Administering Agency

Permits:

Division of Sanitarian Services

Department of Health

4815 West Markham

Little Rock, Arkansas 72201

(501) $661-2171$

Sewage System Standards and Subdivision Approval:

Division of Engineering

Department of Health

4815 West Markham

Little Rock, Arkansas 72201

(501) 66I-2623 
7. Relation to Other State and Federal Programs

Sewage systems in subdivisions located within 2,640 feet of a lake or stream must also conform to the standards of the Department of Pollution Control and Ecology, as described in Section IV, Chapter 5, Part B. 
Generally, the Soil and Water Conservation Commission is responsible for water resource management outside of the incorporated limits of cities and towns. The Commission has permitting authority over the construction of dams. It also must approve all proposed water development projects for conformance with the State Water Plan. The permit process for dam construction and the water development plan approval process are stipulated in Part A and Part B of this Section, respectively.

\section{PART A. Dam Construction and Ownership Permit Process}

1. Authorizing Statute

Act 81 of 1957, as amended (Arkansas Statutes Annotated, Sections 84-1003, et seq.)

2. Title of Regulation

Rules Governing the Arkansas Dam Safety Program.

3. Summary of Permit Process

a. Applicability

The construction of a dam must occur in compliance with the regulations. Levees are exempted from requirements.

b. General Requirements

A permit is required for all dams located on a stream when the dam impounds at least 20 acre/feet of water and when the dam is at or above the ordinary high water mark. 


\section{c. Submittal Requirements}

A completed application form including plans and specifications for the dam must be submitted.

d. Public Hearing

A public hearing is not required; any affected person may request a public hearing within 20 days of public notice.

e. Time Requirements

Once a completed application has been submitted, the permit process normally takes about 30 days. The permit is valid for 50 years.

f. Fees

A fee of $2 \xi$ an acre/foot of water that the dam is designed to impound must be submitted with the application. There is a minimum fee of $\$ 10.00$.

g. Appeals Process

Any person affected by the permit may bring suit against the Commission in Chancery Court.

h. Other Programs Specified in Law

This Act also gives the Commission authority to allocate water during shortages. Any person diverting water from a stream or pond must register with the Commission by completing a registration form. During a shortage, water will be allocated to registered persons before non-registered persons following Department guidelines. 
4. Administering Agency

Soil and Water Conservation Commission

1818 West Capitol, Building A

Little Rock, Arkansas 72202

(501) $371-1611$

5. Relation to Other State and Federal Programs

None specified.

PART B. Arkansas Water Development Plan Review

1. Authorizing Statute

Act 217 of 1969 (Arkansas Statutes Annotated, Sections 21-1317, et seq.)

2. Title of Regulations

Department Guidelines.

3. General Standards

a. Applicability

The undertaking of any water development project is subject to the regulations. A water development project is defined as the "construction, ownership, replacement, operation or maintenance of facilities and works of improvement for the protection, conservation, preservation, development, utilization and proper disposal of the State's . . water for municipal, industrial, agricultural, recreational, and domestic purposes and water for navigation." Water distribution systems and wastewater 
treatment systems within the limits of an incorporated town or city or a water distribution district are exempted.

b. General Requirements and Standards

Plans for water development projects must be submitted to the Commission to insure conformance with the State Water Plan (prepared by the Commission).

c. Submittal Requirements

Preliminary survey and costs of project must be submitted for review.

d. Time Requirements

No time requirements are specified in the regulations.

4. Administering Agency

Soil and Water Conservation Commission

1818 West Capitol, Building A

Little Rock, Arkansas 72202

(501) $371-1611$

5. Relation to Other State and Federal Programs

None specified. 
CHAPTER 8. NON-HAZARDOUS AND HAZARDOUS SOLID WASTE MANAGEMENT

The Arkansas Solid Waste Management Act governs non-hazardous solid waste management in the State of Arkansas. The Solid Waste Disposal Code was developed in 1973 by the Department of Pollution Control and Ecology to implement the Act. The permit process and standards specified in the Code are discussed in Part A of this Section.

Part B describes the regulations for hazardous waste management. There are several acts regulating the disposal and transportation of hazardous wastes in Arkansas. The Arkansas Hazardous Waste Management Act is an approved state program pursuant to the federal Resource Recovery and Conservation Act (RCRA). The Arkansas Department of Pollution Control and Ecology has adopted the Hazardous Waste Management Code for administration of both this Act and a preceding Act, the Arkansas Resource Reclamation Act. The Code stipulates both a permit process and general standards. These requirements are described in Part A and Part B, respectively. Other state acts which apply to hazardous waste management in Arkansas are discussed in Part B under Relation to Other State and Federal Programs.

PART A. Solid Waste Permit Process and Standards

1. Authorizing Statute

Solid Waste Management Act (Arkansas Statutes Annotated, Sections 82-2701, et seq.)

and

Arkansas Water and Air Pollution Control Act, as amended (Arkansas Statutes Annotated, Sections 82-1901, et seq.)

2. Title of Regulation

Solid Waste Disposal Code. 


\section{Summary of Permit Process}

\section{a. Applicability}

The construction, modification or operation of any solid waste processing or disposal facility or disposal site is subject to the regulations. The disposal of household wastes by an individual is exempted from the regulations, provided that such activity does not create a private or public nuisance.

b. General Requirements

A permit is required for each solid waste disposal site or facility.

c. Submittal Requirements

A completed pre-application form identifying the applicant, the purpose of the landfill, and the location of the proposed site must be submitted. If approved, the applicant must then submit a completed application form containing at the very least the following information: the location of the proposed site, a description of soil conditions, access roads and streams in the area, and a topographic map with attached detailed description of proposed construction and operation plans. Other submittal requirements are stated in Chapter 1-Pollution Control Permit Consolidation Process. Further requirements vary by the type of disposal method proposed. A separate permit application form must be completed for incinerators.

d. Public Hearing

A ten day public notice must be issued for all applications for solid waste permits. If five or more written requests for a public hearing are received, a public hearing will be held. 


\section{e. Time Requirements}

The Department should be contacted prior to the application process, so that a preliminary evaluation of the site can be made.

The solid waste disposal permitting process usually requires a minimum of two months depending upon the receipt of the application and the time of the next regular Commission meeting.

Work on a landfill site must begin within six months after the permit is issued.

\section{g. Appeals Process}

Upon the denial of a permit, the applicant may request a hearing before the Commission on Pollution Control and Ecology. The Commission meets regularly on the fourth Friday of odd months and at special meetings as required.

3. General Standards

a. Applicability

The construction and operation of all solid waste disposal sites or facilities and the collection and transportation of solid wastes are subject to the requirements.

b. General Standards and Requirements

Solid waste disposal must be done by one of the following approved methods or a combination of them: 1) sanitary landfill, 2) incineration, 3) composting, 4) other methods fulfilling requirements of the Act. Performance standards are 
specified for the construction and operation of these types of solid waste disposal sites. For example, the regulations specify that at least six inches of material shall be used to cover exposed solid waste in a sanitary landfill each day.

c. Submittal Requirements

No submittal requirements are specified in the regulations.

d. Time Requirements

No time requirements are specified in the regulations.

4. Administering Agency

Solid Waste Division

Department of Pollution Control and Ecology

8001 National Drive

Little Rock, Arkansas 72219

(50।) $371-1 / 35$

5. Relation to Other State and Federal Programs

None specified.

PART B. Hazardous Waste Management Permit Process Standards

1. Authorizing Statute

Arkansas Hazardous Waste Management Act (Arkansas Statutes Annotated, Sections $82-420$, et seq.)

and

Arkansas Resource Reclamation Act (Arkansas Statutes Annotated, Sections 82-4217, et seq.) 
2. Title of Regulation

Arkansas Hazardous Waste Management Code.

3. Summary of Permit Process

a. Applicability

The construction and operation of a hazardous waste management facility or the transportation of hazardous waste is subject to the regulations.

b. General Requirements

A permit is required for all hazardous waste facilities or hazardous waste transporters.

c. Submittal Requirements

A completed application including a description of the site, soils and waste characterization information, the origin of the wastes, and a disaster contingency plan must be submitted.

d. Public Hearing

A public hearing as well as a preliminary hearing are required.

e. Time Requirements

The Director of DPC\&E must notify applicant of the completeness of an application within 180 days of submittal. 


\section{f. Fees}

Fees are prescribed in Section 11 of the Code. Fees are primarily based on the type of ownership (commercial or non-commercial) and number of acres in the landfill.

\section{g. Appeals Process}

No appeals process is specified in the regulations.

3. General Standards

a. Applicability

The storing, collection, transportation, treatment and disposal of any hazardous waste is subject to the regulations.

b. General Standards and Requirements

Performance standards are prescribed for hazardous waste transportation and management. For example, the regulations state that the capacity of hazardous waste storage facilities shall not exceed a volume equal to 90 times the permitted daily processing rate of the treatment process, unless exempted.

Each facility must have at least one operator certified by DPC\&E on duty or on call when the facility is in operation.

c. Submittal Requirements

The owner/operator of a hazardous waste facility must maintain records of operations. 


\section{d. Time Requirements}

No time requirements are specified in the regulations.

4. Administering Agency

Solid Waste Division

Department of Pollution Control and Ecology

800I National Drive

Little Rock, Arkansas 72219

(501) $371-1135$

5. Relation to Other State and Federal Programs

The Arkansas Hazardous Waste Management Act is an approved state program developed pursuant to the federal Resource Conservation and Recovery Act (RCRA).

The transportation of hazardous waste by railroad is governed by Act 651 of 1979 (Arkansas Statutes Annotated, Sections 73-745, et seq.) which requires certain information about the characterization of the hazardous waste cargo.

The Hazardous Materials Transportation Act of 1977 (Arkansas Statutes Annotated, Sections 76-2901, et seq.) regulates the labeling of containers that are transported by any means of transportation. 
CHAPTER 9. NOISE REGULATIONS

There are no state environmental noise control laws. 


\section{CHAPTER 10. WILDLIFE PROTECTION}

State laws do not impose any regulatory authority over the protection of rare and endangered species in Arkansas. However, Act 211 of 1973 requires the Commission to maintain an inventory of habitats of rare, vanishing, or endangered species. The Game and Fish Commission is in the process of compiling a state list of animal species of special concern in Arkanas.

The Commission also issues scientific collecting permits for the collection of animal specimens for official study purposes. The permit process and standards are stated in Part A.

The Game and Fish Commission is a "cooperator" under Section 6(c) of the Endangered Species Act of 1973 which protects rare and endangered species at the federal level. In coordination with the U.S. Fish and Wildlife Service, the Commission may be requested by the project initiator or a government agency to review a proposed project to determine if any rare or endangered species will be affected.

PART A. Scientific Collecting Permit Process and Standards

I. Authorizing Statute

State Constitutional Amendment No. 35.

2. Title of Regulations

Requirements for Obtaining Scientific Collecting Permits from the Arkansas State and Game and Fish Commission. 


\section{Summary of Permit Process}

a. Applicability

Any person collecting animal specimens is subject to the regulations.

b. General Requirements

All persons collecting animal specimens must receive a permit. Permits are given to qualified persons collecting specimens for official business or study purposes. Holders of scientific collecting permits for certain animals must have a current hunting and/or fishing license.

c. Submittal Requirements

A completed application including the applicant's business or academic qualifications; the type and number of specimens that will be collected; why, where, and when the specimens will be collected; and the requested time period for the permit must be submitted.

d. Public Hearing

A public hearing is not required.

e. Time Requirements

The expiration date of the permit will be determined when the permit is issued according to the amount of time required to conduct the collecting. No permit will be valid for longer than 12 months. 
No later than 30 days after the expiration of a permit, the permittee must submit a report of all collections to the Arkansas Game and Fish Commission.

\section{f. Fees}

No fees are required.

\section{g. Appeals Process}

There is no appeals process once a permit has been denied.

\section{General Standards}

\section{a. Applicability}

Any person collecting animal specimens is subject to the regulations.

\section{b. General Standards and Requirements}

Standards have been developed regulating the manner in which animal specimens may be taken. The Regulations prohibit the taking of specimens by the use of chemicals or other electroshocking devices or by the use of lighting devices, unless exempted. Permittee must have a manually signed copy of a scientific collecting permit and hunting/fishing license, if required, while conducting the activity authorized.

\section{c. Submittal Requirements}

Once the permit is received, the permittee is not required to submit additional information until within 30 days after the permit expires. At that time a detailed report of all collections must be submitted. This report must include the name and 
permit number of the collector, name and location of area where collections were made, dates of collections, number and weight of species taken, method of collection, and disposition of all animals taken.

d. Time Requirements

No time requirements are specified in the regulations other than those listed above in Section C.

5. Administering Agency

Arkansas Game and Fish Commission

\#2 Natural Resources Drive

Little Rock, Arkansas 72205

(50I) 223-6300

6. Relation to Other State and Federal Programs

The Scientific Collecting Permit and standards do not authorize any act that is in violation of the Endangered Species Act of 1973. 
CHAPTER 11. ARCHAEOLOGICAL AND HISTORICAL RESOURCES PROTECTION

State laws provide selective protection for archaeological or historical resources on certain lands. Archaeological sites in state or other public lands in Arkansas are protected by Act 58 of 1967. That Act states that the state reserves the right to conduct field archaeology on sites owned or controlled by the State or its agencies in order to protect archaeological and scientific information, matter, and objects. The terms "archaeological," "scientific information," "matter" and "objects" are not defined. Lands where sites or artifacts are located may be reserved from sale by the state upon written notice to the Commission of State Lands by the Arkansas Archaeological Survey. The applicable agency contact is:

Arkansas Archaeological Survey

P.O. Box R

Fayetteville, Arkansas 72701

(50I) 575-3556

The Utility Facility Environmental and Economic Protection Act protects archaeological resources on land on which a utility facility is proposed to be built. The contents of the Act are described in Section VI, Chapter 15, Part A.

Relation to Other State and Federal Programs

The National Environmental Policy Act (NEPA) requires evaluation of the effects of major federal actions on environmental resources, including cultural resources.

Sections 106 of the National Historic Preservation Act (NHPA) directs federal agencies to take into account the effect of a federal, federally assisted, or federally licensed undertaking on a National Register Property or a property that might be eligible for the National Register. This evaluation and appropriate mitigation procedures, if needed, involve the "undertaking" agency representative, the Advisory Council on Historic Preservation, and the State Historic Preservation Officer. The regulations implementing Section 106 are directed 
toward maximum coordination with the environmental review process established by the National Environmental Policy Act.

The administering agency is:

Arkansas Historic Preservation Program

Suite 500

Continental Building

Markham and Main Streets

Little Rock, Arkansas 72201

(501) $371-2763$ 


\section{CHAPTER 12. WETLANDS PROTECTION}

There are no state laws which impose regulatory authority over the protection of wetlands.

Relation to Other State and Federal Programs

The Dredge and Fill Permit Program, and indirectly, the National Pollutant Dishcarge Elimination System (NPDES) permit program provide for the protection of ecologically-sensitive wetlands at the federal level. Any person who proposes to discharge dredged or fill material into waters of the United States must apply for a dredge and fill permit under the first program. Any person who proposes to discharge wastewater in a wate body must apply for a NPDES permit. Under these programs, the Department of Pollution Control and Ecology may review an application and provide comments concerning the effects of any project on wetlands.

The administering agency is:

Environmental Preservation Division

Department of Pollution Control and Ecology

8001 National Drive

Little Rock, Arkansas 72219

(501) $371-1135$ 
SECTION VI. LAND USE

CHAPTER 13. LOCAL GOVERNMENT LAND USE ENABLING LAWS

Arkansas cities of the first and second classes and counties have the authority to enact and enforce land use measures within their corporate boundaries.

PART A. Cities

I. Authorizing Statutes

Arkansas Statues Annotated, Sections 19-2804 et seq.

2. Title of Regulation

None

3. General Standards

a. Applicability

The Act delegates to all cities of the first and second classes the authority to designate and enforce zoning restrictions. A city of the first class is defined as any city with a population of 2,500 inhabitants. A city of the second class is defined as any city with a population between 500 and 2,500.

b. General Standards and Requirements

All cities of the first and second classes may zone any area within the corporate limits of the city. 


\section{c. Submittal Requirements}

The regulations do not require that any information be submitted.

d. Time Requirements

No time requirements are specified in the Act.

Laws authorizing cities and towns to enact and enforce land use measures to prevent flood hazards are discussed in Chapter 14, Part A.

\section{PART B. Counties}

I. Authorizing Statute

Arkansas Statutes Annotated, Sections 17-1107 et seq.

2. Title of Regulation

None

3. General Standards

a. Applicability

The Act delegates to all counties the authority to designate and enforce zoning restrictions.

b. General Standards and Requirements

The county judge of any county may, with the approval of the County Quorum Court, create a County Planning Board. The Board is charged with the duty of regulating land use in the county by passing zoning orginances. Zoning ordinances are to 
be enforced through the issurance of building permits and use permits.

c. Submittal Requirements

The regulations do not require that any information be submitted.

d. Time Requirements

No time requirements are specified in the Act.

Laws authorizing counties to enact and enforce land use measures to prevent flood hazards are discussed in Chapter 14, Part B. 
Local governments and the Arkansas Soil and Water Commission have the authority to enact and enforce land use measures to prevent flood hazards in Arkansas.

\section{PART A. Floodplain Management Enabling Laws}

I. Authorizing Statute

Act 629 of 1969 (Arkansas Statutes Annotated, Sections 21-1901, et seq.)

2. Title of Regulation

Department Guidelines.

3. General Standards

a. Applicability

The Act authorizes cities, towns, counties, and the Arkansas Soil and Water Conservation Commission to enact and enforce any land use measures necessary to prevent and alleviate flood hazards.

b. General Standards and Requirements

Cities, towns, and counties may restrict development and use of land in flood-prone areas. If the Commission finds that any city, town or county has not adopted effective measures such that the National Flood Insurance Program is not available to residents, it may hold a public hearing to prescribe such regulations. The city, town or county officials must enforce any regulations issued by the Commission in this manner. These regulations may 
be modified only with the written consent of the Commission. Nothing, however, would prohibit a city, town, or county from adopting a measure more restrictive than that adopted by the Commission. Any person or corporation who violates any measure adopted under this Act may be fined not more than $\$ 100.00$ for each offense each day during which such violation exists as a separate offense.

\section{c. Submittal Requirements}

The regulations do not require that any information be submitted.

\section{d. Time Requirements}

The Commission must give 30 days notice to a city, town, or county before it prescribes regulations for that entity.

4. Administering Agency

Soil and Water Commission

1818 West Capital, Building A

Little Rock, Arkansas 72202

(501) $371-1611$

5. Relation to Other State and Federal Programs

This program is coordinated with the National Flood Insurance Program. 
PART A. Public Utility Facility Environmental Protection Certification Procedure

I. Authorizing Statute

Utility Facility Environmental and Economic Protection Act (Arkansas Statutes Annotated 73-276 et seq.).

2. Title of Regulations

Rules of Practice and Procedure.

3. Summary of Certificate Process.

a. Applicability

The construction of a major new public utility facility is subject to the regulations. A "major utility facility" means an electric generating plant and associated transportation and storage facilities of 50 megawatt capacity of more. For the sole purpose of requiring an environmental impact statement under this Act, "major utility facility" also means an electric transmission line and associated facilities of 100 kilovolts or more extending for ten miles or 170 kilovolts extending for one mile, or a gas transmission line and associated facilities transporting gas in excess of 125 pounds per square inch extending more than one mile, unless exempted.

b. General Requirements

All major new public facilities must receive a certificate of environmental compatibility and public need. 


\section{c. Submittal Requirements}

A completed application including a description of the facility, an Environmental Impact Statement (EIS), alternate sites, need, financing methods (chosen and alternative), and cost data must be submitted. The EIS must include an analysis of the proposed (preferred and alternative) facilities, direct and indirect effect on the ecology of the land, air and water environment, established park and recreational areas, and on any sites of natural, historic, and scenic resources of the areas. In addition, proof of service of application upon various local officials and agency heads must be submitted.

d. Public Hearings

A public hearing is required.

e. Time Requirements

The Commission must set the date for the public hearing to begin between 40 and 90 days after the receipt of the application.

f. Fees

A $\$ 500.00$ initial filing fee must be submitted with the application.

g. Appeals Process

The certification hearing is normally conducted before an administrative law judge. Any person who is aggrieved by the preliminary order issued by the administrative law judge may appeal to the Commission for review. Any party aggrieved by the Commission's decision may apply for a rehearing by the 
Commission. In the event that the initial certification hearing was heard by the Commission itself, an aggrieved person may also apply for rehearing before that body.

4. Administering Agency

Public Service Commission

Post Office Box C400

Little Rock, Arkansas 72203

(501) $371-1718$

5. Relation to Other State and Federal Programs

During the state EIS process, other state agencies including the Department of Pollution Control and Ecology, the Department of Health, the Game and Fish Commission, the State Historic Preservation Program, and the Archeological Survey are requested to comment on the proposed action. 